\title{
Reflection of Methodologies of Educational Research: Does action research experienced by the students affect learning development and shifted mindset on research of education?
}

\author{
Abdul Halim ${ }^{1,2}$, Wei-Shan Chang ${ }^{1}$ \\ ${ }^{1}$ National Dong Hwa University, ROC (Taiwan) \\ ${ }^{2}$ Universitas Muhammadiyah Kalimantan Timur, Indonesia \\ Email: ah918@umkt.ac.id
}

\begin{abstract}
:
This paper reports reflections of one of the courses I took in this semester namely Methodologies of Educational Research. To construct this paper, I used qualitative biographical-reflective method which is aligned with interpretive paradigm of narrative inquiry research methodology to describe my own experience in the learning process. The data I used were the postings from Zuvio mobile application designed for advising learning process with online platform and personal experience from reflective process of the course. I analyzed the data with three-stage qualitative data analysis: data reduction, data display, and conclusion. The findings report that the classroom undergone with classroom action research has successfully overcome the difficulty faced by professors and students at international $\mathrm{PhD}$ programs. The students were found to perceive positive attitudes towards the carefully selected instructions design of action research with Flipped-Jigsaw approach. The implications were also proposed.
\end{abstract}

Keywords: Action research; Flipped-Jigsaw approach; Reflection; Research methods; Zuvio

\begin{abstract}
Abstrak:
Artikel ini melaporkan refleksi dari salah satu mata kuliah yang saya ambil pada semester ini yaitu Metodologi Penelitian Pendidikan. Untuk menyusun makalah ini, saya menggunakan metode kualitatif biografis-reflektif yang selaras dengan paradigma interpretatif metodologi penelitian inkuiri naratif untuk menggambarkan pengalaman saya sendiri dalam proses pembelajaran. Data yang saya gunakan adalah postingan dari aplikasi mobile Zuvio yang dirancang untuk proses pembelajaran dengan platform online dan pengalaman pribadi dari proses reflektif kursus. Saya menganalisis data dengan tiga tahap analisis data kualitatif: reduksi data, penyajian data, dan penarikan kesimpulan. Temuan penelitian ini menunjukan bahwa kelas yang dilakukan dengan penelitian tindakan kelas telah berhasil mengatasi kesulitan yang dihadapi oleh profesor dan mahasiswa di program $\mathrm{PhD}$ internasional. Para siswa merasakan sikap positif terhadap desain instruksi penelitian tindakan yang dipilih dengan cermat dengan pendekatan Flipped-Jigsaw. Implikasinya juga diusulkan pada artikel ini.
\end{abstract}

Kata kunci: Action research; Pendekatan Flipped-Jigsaw; Refleksi; Metodologi penelitian; Zuvio

\section{INTRODUCTION}

The current trends expect the people to be more educated and it is the aim of many countries for their citizens. The impact of this situation is that more and more people are getting their higher degree (research degree) from various institutions, and National Dong Hwa University (NDHU) was no exception. At the moment, as one of the rising universities in Taiwan NDHU attracts more international students. The reason why the university is of an attraction for international students 
is that the departments provide English as the medium of instruction (EMI). However, it becomes another challenge for the faculty members to lead the classrooms as some of the local students enrolled in the EMI classes have less sufficient English mastery. This was found in the reflection of the faculty member, which later initiated the team who taught Methodologies of Educational Research course to implement Flipped-Jigsaw approach under action research to cope with the problems faced by classroom members and improve the quality of instruction to enhance the students understanding of the materials taught in the course Methodologies of Educational Research.

\section{Problem statement}

To lead the reflection process, I set a problem statements for this report:

1. How do I perceive the learning process?

2. How does the learning process affect my metacognitive construction and contribute to my classroom engagement?

3. How did the issues raised from weekly learning process change or improve my mindset on research on education?

\section{Limitation}

This report is arranged and constructed by my personal reflection during my learning process in the course COE_70800-Methodologies of Educational Research in Fall semester 2020. All the claims and attitudes presented in this report are pure personalized experience. Therefore, it cannot be generalized in broader contexts.

\section{Literature review}

\section{Research paradigms in education}

To layout the understanding, it is actually interesting how the course structures were made up. Research in education cannot stand alone without fundamentals on its ground. On this basis, the very first keywords came into attention: researcher, teacher, professionalism, and curriculum.

Understanding the nature and characteristics of each keyword would help to get to know the later concepts introduced in the course. In order to carry out research, it is important to note what interest do we -researchers- have interests on. If the interest is technical, then scientific testing and proving are the methods to be chosen. It holds characteristics of scientific methodology, hypothesis testing, quantitative, the positivist perspectives. If the interest is practical, then the methodology can be hermeneutic or interpretive. It carries the characteristics of interactionist, phenomenological, ethnographic, existential, naturalistic, narrative, etc. If the interest is emancipatory, then the methodology of critical ideology applied with the characteristics of Political agenda, interrogation of power, transformative potential, concern for social justice and freedom from oppression and from the suppression of generalizable interests; research to change society and to promote democracy (Carr \& Kemmis, 1988; Habermas, 1972). These interests are discussed under the paradigm terms of positivism, interpretivism, and critical ideology.

After presenting and criticizing the previous paradigms such as positivism and interpretivism, Carr \& Kemmis (1988) focused on elaborating critical educational research, specifically action research. Action research is based off the eclectic of positivist and interpretive paradigm. The weaknesses of each are left behind and the strengths are taken. However, it does not only take the strength of each, but it also focuses on how to drive the participants to be 
committed on improvement and development. That's why critical participatory research takes the form of, "like mixed methods research, adopts whatever research methodology will deliver the results that enable action and local development to follow" (Cohen et al., 2018).

Well-known for the spiral of action research, this kind of methodology also did not escape criticism. Carr \& Kemmis (1988) argued that the spiral of action research containing a continuous process of plan-act-observe-reflect is not enough if the mindset of the people involved in the research do not have what they call as "Constructive, Reconstructive, Practice in social context, and Discourse among participants". By having the correct mindset of action research, the authors advocated that development of education can be achieved through self-reflective critical community covered under collaborative teacher-researcher action research.

By utilizing the critical paradigm, the instructors applied several student-centered teaching approaches to the learning process, in order to help them shift the learning process from traditional lectures to more engaging methods to both local Taiwanese and international students. These approaches include flipped classroom and the jigsaw method, as well as the weekly feedback that prompts students to think about their learning process, i.e. the metacognition behind their learning.

\section{Flipped classroom}

Flipped classroom is a typical instruction used by teachers to overcome the problem of students overwhelmed by a bunch of heavy learning materials. This instructional strategy involved activities prior classroom that require the students learn materials before coming to the classroom (Enfield, 2013; November \& Mull, 2012). The characteristics of flipped classroom were exhibited in the course of Methodologies of Educational Research. The classroom required the students to have read the materials (may be from multiple resources) and interact guided by questions raised by their peers. They also respond to discussions so that these reading materials do not have to be taught page by page or thoroughly by the teacher. This would spare time for other constructivist learning activities to occur in the classroom. Therefore, not only students motivation can be enhanced, active engagement as well as students' knowledge can be improved (Hsieh et al., 2017).

\section{Jigsaw method}

The jigsaw method was designed under the cooperative learning theory that aligns with constructivism learning approach (Looi et al., 2008). This method empowered the classroom instruction with the students actively participating in highly engaged classroom. In this course, the students were divided into groups of three or four, members of these 'home groups' would remain the same throughout the course. Each member would be assigned to learn particular sections of the learning materials. Once they have mastered their part, they would join members of other groups who learned the same sections and hence possessed similar expertise to discuss the content. Such a temporary group that focused on the discussion of a specific topic or section may be called the expert group in the original jigsaw method. However, since the learning materials in this course were rather open-ended, expertise of a certain discussion topic is not the main focus, in this paper these groups are referred to as special interest group (SIG). After students enriched their knowledge from the discussion in the SIGs, they would return to their home groups and share the information that they have learnt. By piecing together each member's information from different SIG discussions, the home group would end up with one complete information. This method has been proven to be effective to engage the students and improve the learning 
outcome in many different classrooms with various characteristics (Anderson \& Palmer, 1988; Doymus, 2008; Kardaleska, 2013, Suárez-Cunqueiro, 2017).

\section{Metacognitive process}

Learning how to learn is something that many teachers and students seem to be unaware of. What comes to mind of those who teach and learn is all about what to teach and learn. However, rarely did they think of how the process of coming to understand took place. This process is quite critical for both teacher and students if they expect to have a meaningful learning experience. Standing from this point of view, metacognition -often referred to as "systematic body of knowledge about one's cognition" needs to take a part in the reflection process of learning (Schraw \& Moshman, 1995). Metacognitive process occurs when someone stated to monitor how they learned and what kind of resources and action are needed to process the learning (Smith et al., 2007). The understanding of how their metacognition works would likely to help the students to achieve better in the school subjects (Iwai, 2011).

Multiple approaches in delivering high-content courses in $\mathrm{PhD}$ level are gaining interest of this study to investigate how the students shift their minds and metacognitive learning process in order to carry out the course successfully. The investigation would be in four areas, namely the perception of the learning process, the reflection process on metacognition, classroom engagement, and the learning mindset towards the course. The implication of the study is that the use of multiple approaches instead of traditional lecture which tends to indicate to be not very motivating, would be beneficial to teach a course that requires high cognitive processes.

\section{METHODS}

\section{Participants}

The participants of Methodologies of Educational Research course with code COE_70800 were mixed nationalities from three different countries: Taiwan, the United States of America, and Indonesia. All of them are $\mathrm{PhD}$ students with different backgrounds. Some of them are the faculty members of some different universities from Indonesia, a reporter from the states, school principals from Taiwan, consultants for students of special needs, school teachers, as well as professionals from private companies. The participants were also enrolled in different departments namely Department of Education and Human Potential Development, Department of Education Administration and Management, and Department of Special Education making the participants have varied background with rich and diverse different background knowledge.

\section{Setting}

The learning process took consecutive 18 active weeks of fall semester 2020. The first week begins from September 18, 2020 to January 15, 2021. The teaching and learning process involved various instructional approaches. Flipped classroom was definitely used throughout the process. The students were asked to independently learn the materials before entering the classroom because the reading materials were much and heavy. The learning process was guided by the questions posted by classmates on Zuvio mobile app. Zuvio is an online platform used by the instructors to help the students with guiding questions to read the materials and then let the students answer the questions online. In addition to online discussion, Zuvio also facilitated the students to reflect every time the class ends, as well as facilitated the instructors to conduct formative assessment weekly. The platform is quite convenient with all its features although it has no English language support on its mobile version. 
During the classroom process, there are three stages of English as medium of instruction where in the first stage consisted of $60 \%$ English and $40 \%$ Chinese. In the second stage the instructors used 80\% English and 20\% Chinese. In the third stage, 100\% English was used by the instructors.

In the first stage, the learning process used common classroom process. The sessions were divided into three sessions: presentation, discussion, confirmation. Meanwhile the second and the third session the learning consisted of short presentation, special interest group (SIG; temporary topic-based groups) discussion, home group (consistent initial groups) discussion, and confirmations and reflection.

\section{Data source}

The data in this report were the postings that I have on Zuvio mobile application and personal reflective experience during 18 weeks of the fall semester 2020. This type of data is common for biographical research method. "The biographical approach emphasizes the placement of the individual within a nexus of social connections, historical events and life experiences" (David \& Sutton, 2003). It was collected by reopening past reflections and reviews on the classroom learning process.

\section{Analysis}

To analyze the data, because I used qualitative biographical-reflective method which is a narrative inquiry research methodology to describe my own experience in the learning process, I utilized the most common three-stage qualitative interpretive approach to data analysis: data reduction, data display, and conclusion. I started with data reduction. This refers to the process where the mass of qualitative data is reduced and organized. After data reduction I continued with data display where I presented the organized data in a well-mannered layout so that it is easier to process the third stage, the drawing of the conclusion.

\section{RESULTS AND DISCUSSION \\ Results}

\section{Perception of the learning process}

First, the initial flipped process is the process where the students were required to read the materials before coming to the classroom. The materials were provided by the instructors. What the students need to do was to read and elaborate their answers on the Zuvio online platform since the questions had been posted by their classmates preceding the process. My attitude towards this stage is very positive. The questions posted on Zuvio helped me to organize my reading practice. Since the book is not easy to read due to the use of extensive academic vocabulary and complex grammar, the guiding questions helped me identify the important keywords and concepts. Therefore, as a student I would not get lost in my reading.

Second, the dynamic of discussion from different groups and different backgrounds as well as expertise made the discussion rich of new localized knowledge and examples. Each member, apart from their reading materials, brought their real-life experiences and contributed to the discussion that enriched the theoretical frameworks which were to be learnt from the textbook and other resources of this course. They share and negotiate their understandings and opinions about the content of the week. By engaging in such activities, students had to learn to organize the materials in a more meaningful way (e.g. concepts being linked to experiences) and shared it with the classmates. As suggested by Darling-Hammond et al. (2020) when learning is supported 
by students actively elaborating the materials, it helps to deepen their understandings. Moreover, the fact that students started to make real-world connections, negotiate opinions and understandings, shows evidence of higher order thinking. The engagement of higher order thinking skills is also associated with deeper learning (Hobbins et al., 2020).

\section{The reflection process on metacognition}

Unlike other courses, the course of Methodologies of Educational Research was taught in a unique way. Not only did the professors guided the class to learn the materials from the books and other resources via the aforementioned cooperative learning approaches, but they also encouraged the students to reflect on their own learning weekly. The reflection incorporated aspects like the students' emotions and feelings, time spent for learning, how they conducted their own learning, what obstacles were faced, benefits gained and challenges, etc.

Some items from the reflection questions on Zuvio invited me to contemplate on how my learning process actually happened. I eventually learned what I need to learn and how to achieve the learning goal that I set before. Some questions like the amount of time spent for learning and how much preparation I did before the class, repeatedly, helped me adjust my learning style to meet the demand of the course outline.

Allocating enough time for reflection allows for better regulation of emotions, working out inconsistencies in thought and action, reducing burnout and maximizing professional development (Miller, Ford and Yang, 2020). Although it took some time for the students to fill in the weekly self-reflection survey throughout the course, the survey was accessible until midnight which had made it easier to reflect once all academic activities have finished during the day. Therefore, the reflection can be done with a clearer head to fill in and answer the provided questions. The reflection process also became a critical part of the learning process.

\section{Classroom engagement}

I also perceived the classroom process as an interactive and interesting process. Once coming to the classroom, it was always interesting. Besides following the presentation sessions, some of which were interactive ones, to refresh the materials read by the students, the jigsaw approach had opened opportunity to every student to get involved in a live group discussion. The first group session would be the SIG. In this session those who were interested in the same topic or question posted on the Zuvio would come together, shared their answers, pose their opinions, and sometimes debated some ideas. The concern of noncontributors was faced by many instructors when incorporating group discussions in class. However, the course here is for doctoral students only, which means the students were expected to be independent learners. Also, in each SIG, there would be a discussion leader from the presenting group of the week, who was responsible for mediating the discussion process. The leader would make sure that the discussion stayed on topic and every member had a chance to speak or question. The student's engagements were likely to occur very intensively. Nonetheless, there was also something worth noting, the medium of the SIG discussions was English. Due to some lower English proficiency of some students, their engagement could be low in some occasions. There was a need for a translator and it was responded by the instructor. The freer the students from the language barrier, the higher the engagement can be.

\section{The learning process towards my mindset on research on education}

Research in any contexts need a paradigm to set as a loop or magnifying glass to be used on how the researcher sees a truth. It is very important since the proper paradigm would help the 
researcher reveal the truth they seek with correct methodology. If they did not set off from the appropriate paradigm and method, whatever the results they announce would not be valid nor reliable.

The learning process from this course has some very interesting dialectical process on my understanding of each paradigm. It invited us, the students, not only to know those paradigms, but also to be aware of what strength and weakness as well as the criticism of each, and then engage in dynamic discussions regarding the applicability of these paradigms in the context of educational research. I always thought that there was one paradigm that was superior among others, making me one-sided. But enrolling in this course has opened my mind to not rely heavily on one paradigm and mentioning that others are bad. The critical context the course brought has exhibited evidence of how a critical point of view can be applied to a certain paradigm in the research of education. The presence of argumentative content and discussion was found to be conducive to students' critical thinking skills (Giri and Paily, 2020). Like a student's testimony, his mind kept changing following the paradigms being discussed in the chapters throughout the course. Similar mindset changes also happened to me. It was always exciting to follow each session as there would be enrichment and criticism on what we understood of how to reveal the truth through research.

However, for once in a while, I was thinking that action research would not affect anything. We tried to bring about the change and improve the situation based on the analyzed current problems. Then, the action was taken. Changes were to occur, but I did not see their possibility to be a sustainable development for the society. I was wrong. The un-sustainable change that might occur was due to the characteristics of participatory action research did not really take a place. When it started wrong, nothing more can be expected. This very basic logic has developed over the course.

\section{Discussion}

Overall, it was pleasantly unexpected that the combination of flipped and jigsaw approaches became the motor to mobilize the learning process in the classroom. It has helped the students in at least three ways. First, student learning has shifted from a passively receiving to a more active and constructive manner. Second, the learning process has 'forced' the students to extend their learning from within to beyond the classroom. The third is that it helped students to be aware of their metacognitive process.

The instructional approach used in this course was implemented through constructivism. The learning paradigm of constructivism has been the current trend for improving the learning process. And, the benefit of the flipped jigsaw method has been found in various fields of education such as biochemistry (Uppal and Uppal, 2020) and management (Costouros, 2020). The process is not only for engaging the students within the classroom context, but it also holds essential meaning for the student's knowledge acquisition. It supports the learning process on changing the mindset of the students, they would own up more to their own learning and dig deeper into the topics. This not only result in better performance but also longer retention of the learned knowledge in the future (Tran, 2016). Furthermore, as many students enrolled in this course were frontline educators, they would connect the topics of the course with their own experiences and reflect on them. Such a reflection would likely be brought to their own practices, and lead to what Dewey suggested the reconstruction or reshaping of the society (Carr \& Kemmis, 1988).

The contents of the course were all in English, which was considered a 'foreign' language for the majority of the students here. Learning contents that are very academic was already pretty 
challenging, having to learn it via a foreign language would make it even more stressful. Fortunately, the jigsaw method was found to help reduce such an anxiety (Goda et al., 2016), and they would become a bit more confident and willing to study for the course. Furthermore, since the students were responsible for in-class presentations and SIG discussions, they have to prepare the materials before class. Giving students the autonomy of leading the presentations and discussions also provided them with the chance to build their concepts based on their own interests, prior knowledge and experiences. With greater sense of responsibility and autonomy on their own learning, it motivated the students to spend more time preparing, processing and extending the materials beyond the classroom.

The weekly self-reported feedback included survey questions that prompt the students to reflect on the process of their own learning. Students were asked to think about how much time they had spent studying for the course each week, how much they contributed in class and during group work, and the difficulties they had encountered. The weekly helped raise the students' awareness of their metacognitive process. With such an awareness, the students would then be able to see what factors were influencing their learning. Being able to target these factors, students would be able to improve on their learning strategies. Research has also found that explicit practices of metacognitive reflections has significant impact on the acquisition of domain knowledge, i.e. the knowledge of a specialized discipline (Cromley and Kunze, 2020).

The next, "I was wrong." That is the thought that comes to mind when reaching the threefourth of the sessions that I thought action research does not bring any sustainable changes for the society. It is not the action research that is not effective for bringing about the changes. Rather, it is the centrality of power distribution and regards on local community knowledge that would help sustaining the changes. Let us see it from two perspectives.

Firstly, from the perspective of students in this course. I found that the course which was designed with action research approach has given me more opportunity to participate more than ever since it is more centralized on the students. They also got equal power as well as elaborating the ideas based on their local knowledge and shared it with classmates from different countries and cultures. It characterized the improvement and empowerment (Cohen et al., 2018).

Secondly, from the theoretical perspective, it fulfils the terms and condition of action research that required good communication, fair decision-making, and satisfying collaborative works (Carr \& Kemmis, 1988). Different from other paradigms, i.e. where positivist focusing on technical effectivity and disregards the characterization of educational practice or where the interpretivist focusing in interpreting and understanding the problem in the society but does not change status quo, participatory action research focuses on empowerment and development of the society within its context to be the medium for the research itself as the outcome (Cohen et al., 2018). Therefore, the terms and condition of critical approach of participatory action research should apply.

\section{CONCLUSIONS}

This reflection report has showed that the learning process designed in the course of Methodologies of Educational Research perceived positive attitude from the students. In addition, the learning process also helped the students to be aware of their cognition process which lead the students to be able to cope with their personal problems through reflections. Its construction is also supported by Zuvio app that records all the reflections and the review as well as quizzes the students filled in every week. The learning has also been found to be meaningful and engaging for the students. Furthermore, the aim of the course can be achieved that the students exhibit the 
understandings related to the materials taught in the classroom. The process has reflected a good action research and met the criteria of good action research.

\section{REFERENCES}

Anderson, F. J., \& Palmer, J. (1988). The jigsaw approach: Students motivating students. Education, 109(1).

Carr, W., \& Kemmis, S. (1988). Becoming Critical: Education, Knowledge, and Action Research (Vol. 13, Issue 1). RoutledgeFarmer, Taylor \& Francis Inc. https://doi.org/10.2307/1495177

Cohen, L., Manion, L., \& Morrison, K. (2018). Research Methods in Education (8th ed.). Taylor and Francis. http://library1.nida.ac.th/termpaper6/sd/2554/19755.pdf

Costouros, T. (2020). Jigsaw Cooperative Learning versus Traditional Lectures: Impact on Student Grades and Learning Experience. Teaching \& Learning Inquiry, 8, 154-172. https://doi.org/10.20343/teachlearninqu.8.1.11

Cromley, J., \& Kunze, A. (2020). Metacognition in education: Translational research. Translational Issues in Psychological Science, 6(1), 15-20. https://doi.org/10.1037/tps0000218

Darling-Hammond, L., Flook, L., Cook-Harvey, C., Barron, B., \& Osher, D. (2020). Implications for educational practice of the science of learning and development. Applied Developmental Science, 24(2), 97-140. https://doi.org/10.1080/10888691.2018.1537791

David, M., \& Sutton, C. D. (2003). The A-Z of Social Research. In Sociological Research Online (Vol. 8, Issue 4). SAGE Publication. https://doi.org/10.1177/136078040300800411

Doymus, K. (2008). Teaching chemical equilibrium with the jigsaw technique. Research in Science Education. https://doi.org/10.1007/s11165-007-9047-8

Enfield, J. (2013). Looking at the Impact of the Flipped Classroom Model of Instruction on Undergraduate Multimedia Students at CSUN. Tech Trends, 57(6), 14-27. http://ehis.ebscohost.com.ezproxy.strose.edu/ehost/pdfviewer/pdfviewer?vid=6\&sid=432 4c770-0fa1-45f9-8305-58c23246b361\%40sessionmgr4004\&hid=4111

Giri, V., \& Paily, M. (2020). Effect of Scientific Argumentation on the Development of Critical Thinking. Science \& Education, 29, 673-690. http://dx.doi.org/10.1007/s11191-02000120-y

Goda Y., Yamada M., Hata K., Matsukawa H., Yasunami S. (2017) Effects of Flipped Jigsaw Collaborative Learning on English as a Foreign Language Learning Anxiety. In: Wu TT., Gennari R., Huang YM., Xie H., Cao Y. (eds) Emerging Technologies for Education. SETE 2016. Lecture Notes in Computer Science, vol 10108. Springer, Cham. https://doi.org/10.1007/978-3-319-52836-6_69Habermas, J. (1972). Knowledge and Human Interests. Heinemann.

Hobbins, J., Murrant, C., Snook, L., Tishinsky, J., \& Ritchie, K. (2020). Incorporating higher order thinking and deep learning in a large, lecture-based human physiology course: can we do it? Advances in Physiology Education, 44(4), 670-678. https://journals.physiology.org/doi/full/10.1152/advan.00126.2019

Hsieh, J. S. C., Wu, W.-C. V., \& Marek, M. W. (2017). Using the flipped classroom to enhance EFL learning. Computer Assisted Language Learning, 30(1-2), 1-21. https://doi.org/DOI: $10.1080 / 09588221.2015 .1111910$

Iwai, Y. (2011). The Effects of Metacognitive Reading Strategies: Pedagogical Implications for EFL/ESL Teachers. Reading, 11(2), 150-159. http://readingmatrix.com/articles/april_2011/iwai.pdf

Looi, C. K., Lin, C. P., \& Liu, K. P. (2008). Group Scribbles to Support Knowledge Building in Jigsaw Method. IEEE Transactions on Learning Technologies, 1(3), 157-164. https://doi.org/10.1109/TLT.2008.20

Miller, J., Ford, S., \& Yang, A. (2020). Elevation through reflection: closing the circle to improve librarianship. Journal of the Medical Library Association, 108(3), 353-363. 
doi:10.5195/jmla.2020.938

November, A., \& Mull, B. (2012). Flipped Learning: A Response To Five Common Criticisms. NovemberLearning.Com. https://novemberlearning.com/article/flipped-learning-aresponse-to-five-common-criticisms-article/

Schraw, G., \& Moshman, D. (1995). Metacognitive theories. Educational Psychology Review, 7(4), 351-371. https://doi.org/10.1007/BF02212307

Smith, K. S., Rook, J. E., \& Smith, T. W. (2007). Increasing Student Engagement Using Effective and Metacognitive Writing Strategies in Content Areas. Preventing School Failure: Alternative Education for Children and Youth, 51(3), 43-48. https://doi.org/10.3200/psfl.51.3.43-48

Suárez-Cunqueiro, M. M., Gándara-Lorenzo, D., Mariño-Pérez, R., Piñeiro-Abalo, S., PérezLópez, D., \& Tomás, I. (2017). Cooperative learning in 'Special Needs in Dentistry'for undergraduate students using the Jigsaw approach. European Journal of Dental Education, 21(4), e64-e71.

Uppal, V., \& Uppal, N. (2020). Flipped jigsaw activity as a small group peer-assisted teaching learning tool in Biochemistry Department among Indian Medical Graduate: An experimental study. Biochemistry and Molecular Biology Education, 48(4), 337-343. https://iubmb.onlinelibrary.wiley.com/doi/abs/10.1002/bmb.21355

Van Dat, T. (2016). The Effects of Jigsaw Learning on Students' Knowledge Retention in Vietnamese Higher Education. International Journal of Higher Education, 5, 236-253. https://doi.org/10.5430/ijhe.v5n2p236 